\title{
Nonlinear Effect of R\&D Expenditures and Intangible Assets on Financial Performance: A Panel Threshold Analysis
}

\author{
Geoffrey VanderPal \\ Purdue University Global
}

The financial outcomes of research and development ( $R \& D)$ expenditures and intangible assets are not instantaneous and straightforward. To explore the varied perspectives of these relationships, this study employs panel threshold analysis. Analysis reveals significant variances in multiple regimes. The findings provide insights in the risk-return paradigm of R\&D investment, dynamics of threshold points and the successive return, besides helping the policy makers to settle the priority sector to get the expected result in line with country's investment policy.

Keywords: Financial Performance, Corporate Finance, Intangible Assets, Research and Development Expense, Corporate Performance, Financial Metrics, Financial Analysis

Recognizing the significance, in recent years, there has been an increasing interest in academics from different field of studies to understand the relationship dynamics between Research and development (R\&D) expenditures and financial performance. Investments in $R \& D$ are considered in relation to other intangible investments, as an important form of investment (Leitner, 2005). At large, R\&D expense and intangibles have positive effects on firm value and profitability, and an indicator for future financial performance (Chen, Cheng, \& Hwang, 2005). However, previously published studies on the effect of $R \& D$ expenses and intangible assets are not consistent. What is less clear is the nature of relationship for diverse sectors - whether and how such relationship dynamics varies. Panel threshold model extends the understanding regarding the level of $R \& D$ expenses and ascertains the regime switching point for such investment activities.

In recent days, it has become an inquiry whether the relationship between firm's R\&D expenditures and financial performance is linear or non-linear. To be specific, is there existence of multiple regimes referring to threshold effect. In case of linear relationship, additional expenditures in R\&D will be associated with similar level of increment in financial performance. However, in presence of non-linear relationship, there will be multiple regimes means that after a certain level of R\&D expenditures financial performance can be negative or insignificant to R\&D expenditures. As suggested by (McAllister \& Wagner, 1981) in an earlier study, Research funding has non-linear effect on its output. For example, allocating the budget for R\&D projects provides supports to run the project, doesn't guarantee the success that turns into better financial performance. Smaller amounts of R\&D expenditures at the beginning may produce better performance while expenditures beyond the threshold level may be related to its past performance rather funding for the current period. In this context, this study investigates in which extent the relationship between financial performance and $R \& D$ expenditures, Intangible assets is affected by the non-linearities and other factors related to this firm's financial performance. The study weighs up the 
non-linear nature of expenditure in R\&D activities and intangible assets by employing panel threshold analysis.

This study aims to contribute to this growing area of research by exploring the relationship from diverse viewpoints. Primarily, the study wants to investigate the relationship between R\&D expenditures made by the firms and their financial performance. Similarly, the study aims to examine the role of corporate intangible assets on their financial performance. Besides looking into the R\&D expense, it considers the ratio of such expense to operating income. Also, it considers the ratio of intangible assets to firm's total assets to cognize how much the possession of intangibles are beneficial from the perspective of firm's asset holding. Considering the non-linearity of spending in R\&D activities, this study uses the threshold analysis which is very distinctive approach in this field of study.

Threshold analysis is intended to shed light on the level of R\&D expenditure and intangible assets holding in different regimes as well as to suggest the inception of such change. For this study, we collected the data from Compustat's S\&P 500 companies. Data frequency is annua,1 and it covers the period from 1979 to 2015 . The table below summarizes the methodological aspects for the current study.

\begin{tabular}{|l|l|l|l|}
\hline 1. & $\begin{array}{l}\text { To Analyse the } \\
\text { threshold effect of the } \\
\text { regime dependent } \\
\text { variables in different } \\
\text { regimes. }\end{array}$ & $\begin{array}{l}\text { Threshold Variables: R\&D } \\
\text { Expense (RDE), Intangible } \\
\text { Assets (INT) } \\
\text { Regime Variables: Assets- } \\
\text { toatal (AST), Sales-net } \\
\text { (SAL) }\end{array}$ & $\begin{array}{l}\text { Static Panel Threshold Analysis to } \\
\text { recognize the level of R\&D expenditure } \\
\text { and intangible assets holding in different } \\
\text { regimes; also to identify the inception of } \\
\text { such change. }\end{array}$ \\
\hline
\end{tabular}

Threshold regression models or sample models have wide application in economics and applied econometric practice (Hansen 1999; Hansen 2000). It allows to endogenously determine the threshold level(s) at which the sample is split. It treats the threshold value(s) as unknown instead of arbitrarily deciding the splitting. The asymptotic distribution of this test statistic is non-standard as the parameter is not identified under the null hypothesis. Hansen (1996) and Caner and Hansen (2004) suggest a bootstrapping procedure to obtain the asymptotic $\mathrm{p}$-value. This paper tries to investigate the threshold effects on financial performance at different levels of R\&D expenditure and intangible assets. Two variables, namely assets and sales, capture the threshold impact of R\&D expenditure and financial performance linkage. It also imposes a priori restriction that the effect of such expenditure on performance monotonically and symmetrically changes with the changes of R\&D expenditure. Certain level of $R \& D$ investment may need to have an impact on firms' financial performances. Moreover, negative ranges of R\&D expenditure-financial performance linkage differ in absolute impact compared to positive ranges: this is accommodated in threshold model, not a quadratic specification. In addressing this issue, this study employs a regression model that based on concept of threshold effects to analyse how expenditures made for company's R\&D activities affects their financial performance. This model allows the linkage between R\&D expenditure and financial performance to be piecewise linear along with the levels of company's assets and sales level acting as regime-switching trigger.

This model allows the linkage between Research and Development expenditures (RnD), Intangible assets (INT) and financial performance (FIN) to be piecewise linear along with the levels R\&D acting as regime-switching trigger.

$$
\begin{aligned}
& \text { FINit }=\mu i+\beta 1 \operatorname{RnDitI}(\operatorname{RnDit} \leqslant \lambda)+\delta 1 \mathrm{I}(\operatorname{RnDit} \leqslant \lambda)+\beta 2 \operatorname{RnDitI}(\operatorname{RnDit}>\lambda)+\gamma \mathrm{Xit}+\theta \mathrm{t}+\varepsilon i t \\
& \text { FINit }=\mu \mathrm{i}+\beta 1 \mathrm{INTitI}(\mathrm{INTit} \leqslant \lambda)+\delta 1 \mathrm{I}(\mathrm{INTit} \leqslant \lambda)+\beta 2 \mathrm{INTitI}(\mathrm{INTit}>\lambda)+\gamma \mathrm{Xit}+\theta \mathrm{t}+\varepsilon \mathrm{it}
\end{aligned}
$$

There are mainly three steps to estimate the coefficients using this model. Firstly, a regression that is in a reduced form is estimated for endogeneous variables Xit, as a function of instruments, Zit by ordinary least square, and obtain the values of bXit. Secondly, substituting the predicted values of bXit in threshold equation, threshold parameter $\mathrm{k}$ is estimated. Resulting sum of squared residuals is denoted by $\mathrm{S}(\gamma)$. It is 
repeated for a strict subset of the support of the threshold variable R\&D expenditures $(\mathrm{RnD})$ or Intangible assets(INT). At last, estimator of threshold value $\gamma$ is selected as it is associated with smallest sum of squared residuals.

However, there are still possibilities of biased standard errors or biased estimated parameters as reported by (Windmeijer, 2005). To address these issues, Law \& Singh, 2014) suggested to reduce the dimensionality of instrumental variables matrix. Therefore, we reduce the instruments count to $1(\mathrm{p}=1)$ to avoid the overfit of instrumented variables which may lead to the estimation of a biased coefficient. All these unique features make it most suitable method to employ to address the second issue of this study that is determining threshold of $R \& D$ expenditure - financial performance along with intangible assetfinancial performance relationships.

TABLE 1

THRESHOLD ANALYSIS: R\&D EXPENSES

\begin{tabular}{lllll}
\hline & ROA & ROE & ROA & ROE \\
\hline $\begin{array}{l}\text { Threshold estimator } \\
\text { (RDE) }\end{array}$ & 3014 & 5477 & 625.55 & 5477 \\
\hline Range (Lower - Upper) & $2813-3135$ & $265.9-5500$ & $265.90-5500$ & $5408-5500$ \\
\hline
\end{tabular}

\begin{tabular}{|c|c|c|c|c|}
\hline Regime Dependent & & & & \\
\hline AST (Regime 1) & $-0.0000697^{* *}$ & -0.0000649 & & \\
\hline & $(-3.01)$ & $(-0.93)$ & & \\
\hline AST (Regime 2) & $-0.000131^{* * *}$ & $-0.000240^{* *}$ & & \\
\hline & $(-6.31)$ & $(-3.05)$ & & \\
\hline SAL (Regime 1) & & & -0.00000592 & -0.0000649 \\
\hline & & & $(-0.33)$ & $(-0.93)$ \\
\hline SAL (Regime 2) & & & $-0.0000692^{* *}$ & $-0.000240^{* *}$ \\
\hline & & & $(-2.92)$ & $(-3.05)$ \\
\hline Regime Independent & & & & \\
\hline NEI & $\begin{array}{l}0.00112^{* * *} \\
(11.46)\end{array}$ & $\begin{array}{l}0.00363^{* * *} \\
(9.53)\end{array}$ & $\begin{array}{l}0.00109^{* * *} \\
(11.07)\end{array}$ & $\begin{array}{l}0.00363^{* * *} \\
(9.53)\end{array}$ \\
\hline EBI & $\begin{array}{l}-0.000784^{*} \\
(-2.18)\end{array}$ & $\begin{array}{l}-0.00306^{*} \\
(-2.16)\end{array}$ & $\begin{array}{l}-0.000216 \\
(-0.63)\end{array}$ & $\begin{array}{l}-0.00306^{*} \\
(-2.16)\end{array}$ \\
\hline INT & $\begin{array}{l}-0.0000715 \\
(-1.32)\end{array}$ & $\begin{array}{l}-0.0000141 \\
(-0.09)\end{array}$ & $\begin{array}{l}0.0000397 \\
(0.96)\end{array}$ & $\begin{array}{l}-0.0000141 \\
(-0.09)\end{array}$ \\
\hline OPI & $\begin{array}{l}0.000797^{*} \\
(2.08)\end{array}$ & $\begin{array}{l}0.00271 \\
(1.84)\end{array}$ & $\begin{array}{l}0.000312 \\
(0.90)\end{array}$ & $\begin{array}{l}0.00271 \\
(1.84)\end{array}$ \\
\hline PRI & $\begin{array}{l}0.00481 \\
(1.39)\end{array}$ & $\begin{array}{l}0.0334^{*} \\
(2.52)\end{array}$ & $\begin{array}{l}0.00773^{*} \\
(2.24)\end{array}$ & $\begin{array}{l}0.0334^{*} \\
(2.52)\end{array}$ \\
\hline SAL & $\begin{array}{l}-0.0000190 \\
(-1.06)\end{array}$ & & & \\
\hline
\end{tabular}




\begin{tabular}{lllll}
\hline & ROA & ROE & ROA & ROE \\
\hline AST & & $-0.000284^{* * *}$ & $-0.000111^{* * *}$ & $-0.000284^{* * *}$ \\
& & $(-3.82)$ & $(-5.78)$ & $(-3.82)$ \\
Constant & $7.613^{* * *}$ & $18.97^{* * *}$ & $8.430^{* * *}$ & $18.97^{* * *}$ \\
& $(15.91)$ & $(11.32)$ & $(21.41)$ & $(11.32)$ \\
\hline$R^{2}$ & 0.241 & 0.182 & 0.245 & 0.182 \\
AIC & 5147.3 & 7985.8 & 5142.1 & 7985.8 \\
BIC & 5191.9 & 8030.4 & 5186.7 & 8030.4 \\
F & 32.99 & 23.21 & 33.67 & 23.21 \\
Observations & 1050 & 1050 & 1050 & 1050 \\
\hline$t$ statistics in parentheses ${ }^{*} p<0.05,{ }^{* * *} p<0.01,{ }^{* * *} p<0.001$ & &
\end{tabular}

In this table, RDE is the threshold variable. In all four models, it is found to have the existence of threshold of RDE to its effect on financial performance of the corporate firms. Asset size and net sales are considered as regime dependent variables. $R \& D$ and financial performance nexus is affected by asset size but not in the same level, it has different effect in different regimes. For ROE, RDE is not significant at regime 1, but after the threshold level in regime 2, it's significant and negatively correlated. For ROA, in both regimes, it's significant and negatively correlated. Net sales is found not to have any significant effect on R\&D expenses and financial performance nexus in regime 1, but negative effect in regime 2 .

TABLE 2

THRESHOLD ANALYSIS - INTANGIBLE ASSETS

\begin{tabular}{|c|c|c|c|c|}
\hline & ROA & ROE & $\mathrm{ROA}$ & ROE \\
\hline $\begin{array}{l}\text { Threshold estimator } \\
\text { (INT) }\end{array}$ & 275.8630 & 4337.1000 & 107.7360 & 872.2000 \\
\hline Range (Lower - Upper) & $271-277.1$ & $4301.2-4456.8$ & $101-110$ & $802-883$ \\
\hline \multicolumn{5}{|l|}{ Regime Dependent } \\
\hline \multirow[t]{2}{*}{ Regime 1 (AST) } & -0.0000448 & -0.0000436 & & \\
\hline & $(-1.37)$ & $(-0.60)$ & & \\
\hline Regime 2 (AST) & $-0.000106^{* * *}$ & $-0.000237^{* *}$ & & \\
\hline \multirow[t]{2}{*}{ Regime 1 (SAL) } & & & $-0.0000662^{*}$ & -0.0000436 \\
\hline & & & $(-2.48)$ & $(-0.60)$ \\
\hline \multirow[t]{3}{*}{ Regime 1 (SAL) } & & & -0.0000209 & $-0.000237^{* *}$ \\
\hline & & & $(-1.15)$ & $(-2.90)$ \\
\hline & $(-6.06)$ & $(-2.90)$ & & \\
\hline \multicolumn{5}{|l|}{ Regime Independent } \\
\hline NEI & $\begin{array}{l}0.00113^{* * *} \\
(11.50)\end{array}$ & $\begin{array}{l}0.00376^{* * *} \\
(9.91)\end{array}$ & $\begin{array}{l}0.00113^{* * *} \\
(11.53)\end{array}$ & $\begin{array}{l}0.00376^{* * *} \\
(9.91)\end{array}$ \\
\hline EBI & $\begin{array}{l}-0.000580 \\
(-1.56)\end{array}$ & $\begin{array}{l}-0.00185 \\
(-1.27)\end{array}$ & $\begin{array}{l}-0.000388 \\
(-1.02)\end{array}$ & $\begin{array}{l}-0.00185 \\
(-1.27)\end{array}$ \\
\hline $\mathrm{RDE}$ & $\begin{array}{l}-0.000592 \\
(-1.73)\end{array}$ & $\begin{array}{l}-0.0000345 \\
(-0.03)\end{array}$ & $\begin{array}{l}-0.000483 \\
(-1.41)\end{array}$ & $\begin{array}{l}-0.0000345 \\
(-0.03)\end{array}$ \\
\hline
\end{tabular}




\begin{tabular}{|c|c|c|c|c|}
\hline & ROA & ROE & $\mathrm{ROA}$ & ROE \\
\hline OPI & $\begin{array}{l}0.000460 \\
(1.18)\end{array}$ & $\begin{array}{l}0.00123 \\
(0.81)\end{array}$ & $\begin{array}{l}0.000364 \\
(0.93)\end{array}$ & $\begin{array}{l}0.00123 \\
(0.81)\end{array}$ \\
\hline PRI & $\begin{array}{l}0.00819^{*} \\
(2.18)\end{array}$ & $\begin{array}{l}0.0315^{*} \\
(2.17)\end{array}$ & $\begin{array}{l}0.00945^{*} \\
(2.52)\end{array}$ & $\begin{array}{l}0.0315^{*} \\
(2.17)\end{array}$ \\
\hline SAL & $\begin{array}{l}0.0000162 \\
(0.75)\end{array}$ & $\begin{array}{l}-0.000232^{* * *} \\
(-3.42)\end{array}$ & & \\
\hline AST & & & $\begin{array}{l}-0.000106^{* * *} \\
(-6.05)\end{array}$ & $\begin{array}{l}-0.000232^{* * *} \\
(-3.42)\end{array}$ \\
\hline Constant & $\begin{array}{l}7.775^{* * *} \\
(16.27)\end{array}$ & $\begin{array}{l}21.29^{* * *} \\
(14.11)\end{array}$ & $\begin{array}{l}8.702^{* * *} \\
(21.41)\end{array}$ & $\begin{array}{l}21.29^{* * *} \\
(14.11)\end{array}$ \\
\hline$R^{2}$ & 0.239 & 0.178 & 0.242 & 0.178 \\
\hline$A I C$ & 5149.9 & 7991.9 & 5146.0 & 7991.9 \\
\hline$B I C$ & 5194.5 & 8036.5 & 5190.6 & 8036.5 \\
\hline $\mathrm{F}$ & 32.65 & 22.47 & 33.17 & 22.47 \\
\hline Observations & 1050 & 1050 & 1050 & 1050 \\
\hline
\end{tabular}

$t$ statistics in parentheses $p<0.05,{ }^{* *} p<0.01,{ }^{* * *} p<0.001$

In this table 18, INT - Intangible assets is the threshold variable. In all four models, it is found to have the existence of threshold of INT to its effect on financial performance of the corporate firms. Asset size and net sales are considered as regime dependent variables. Intangible assets and financial performance nexus is affected by asset size but not in same level, it has different effect in different regimes. Asset size does not have any effect in regime 1 as it is found statistically insignificant, but in regime 2 , it is found to statistically significantly and negatively correlated. Asset class effect is only be true after the threshold level in regime 2. Net sales negatively affect Intangible assets and ROA nexus in regime 1 , but not in regime 2 . On the other hand, it affects INT - ROE nexus in regime 2 only, not in regime 1.

The current study intended to examine the relationship between R\&D expense and corporate financial performance as well such how such financial performance is influenced by firms' intangible assets. To do so, the study considers the ratio of R\&D expense and operating income and the ratio of intangible assets to firm's total assets besides considering R\&D expenses and intangibles assets to measure the relationship. By employing the data from S\&P 500 companies over the period of 1979 to 2015, the study finds diverse outcomes concerning the relationship. The study weighs up the non-linear nature of expenditure in R\&D activities, therefore, employs the threshold analysis. The analysis found dissimilarities in different regimes; size and total sales has differing effect in various threshold regimes of $\mathrm{R} \& \mathrm{D}$ expenses as well as intangible assets.

The research findings possess significant policy implications for different class of stakeholders as $\mathrm{R} \& \mathrm{D}$ expenditures and intangible assets are intense concerns for various parties. For the investors, the findings provide insights in risk-return paradigm in the framework of investment risk in R\&D activities and intangible assets holding by the firms and their subsequent return. The findings are also expected to help the financial managers to forecast the future return of a firm and also to measure the riskiness of financing and investment activities. For instance, the threshold analysis outcomes allow them to comprehend how much investment is needed to reach the threshold level and the successive return besides helping in determining the budget, sales and so on. In addition, this study contains noteworthy insights for the policy makers, government agencies and regulatory bodies; returns generated through $\mathrm{R} \& \mathrm{D}$ expenditures and intangible assets are vital to decide on the benefits, subsidization, taxation policy and such. Further, it is expected to aid the policy makers to settle on which sectors are worthy to be prioritized and how much be supported to get the expected result in line with country's investment policy. 
Also, notably the study adds value to academia by considering R\&D expenses and intangibles' influence on corporate performance which is not clear in the existing literature. Besides answering some unsettled research problems and adding knowledge to the growing body of literature in this field, the study unveils further avenue of research for academics.

The study endeavoured comprehensive analyses and a fairly novel attempt to understand the nexus; nevertheless, it is not devoid of some limitations mostly owing to unavailability of adequate data. The dataset comprises only S\&P 500 companies which are predominantly large companies based on a developed economy (i.e. the USA), thus leading to a lack of generalizability of the findings for the companies around the globe. Also, in some cases sufficient sectoral data were not available and levied restrictions on analyses. Likewise, the study did not take into consideration the institutional and governance variables. Since significant difference is found in asset-equity structure of the companies, further analyses with such variables could have been more insightful. Correspondingly, the analyses do not expands to consider regional variations of the firms' spending in R\&D activities, thus the study does not provide how the relationship varies region-wise, i.e. how the developed country firms get benefits from $R \& D$ expenses and intangibles assets compared to developing ones. Hence, future research may consider new datasets and incorporate regional analyses by giving consideration for institutional and political variables which will stretch better generalizability of the research. Furthermore, study can be further extended by considering threshold and asset size effect for different sectors as the current finding is somewhat heterogeneous.

\section{REFERENCES}

Arrighetti, A., Landini, F., \& Lasagni, A. (2014). Intangible assets and firm heterogeneity: Evidence from Italy. Research Policy, 43(1), 202-213.

Bottazzi, G., \& Secchi, A. (2003). Common properties and sectoral specificities in the dynamics of US manufacturing companies. Review of Industrial Organization, 23(3-4), 217-232.

Bottazzi, G., Secchi, A., \& Tamagni, F. (2007). Productivity, profitability and financial fragility: empirical evidence from Italian business firms.

Cainelli, G., Evangelista, R., \& Savona, M. (2005). Innovation and economic performance in services: a firm-level analysis. Cambridge Journal of Economics, 30(3), 435-458.

Cazavan-Jeny, A., Jeanjean, T., \& Joos, P. (2011). Accounting choice and future performance: The case of R\&D accounting in France. Journal of Accounting and Public Policy, 30(2), 145-165.

Cecchetti, S., \& Kharroubi, E. (2012). Reassessing the impact of finance on growth (No. 381). Bank for International Settlements.

Cha, H. S., Pingry, D. E., \& Thatcher, M. E. (2009). What determines IT spending priorities? Communications of the ACM, 52(8), 105-110.

Chen, M.-C., Cheng, S.-J., \& Hwang, Y. (2005). An empirical investigation of the relationship between intellectual capital and firms' market value and financial performance. Journal of Intellectual Capital, 6(2), 159-176.

Coad, A., \& Rao, R. (2010). Firm growth and R\&D expenditure. Economics of Innovation and New Technology, 19(2), 127-145.

Dave, P., Wadhwa, V., Aggarwal, S., \& Seetharaman, A. (2013). The impact of research and development on the financial sustainability of information technology (IT) companies listed on the S\&P 500 index. Journal of Sustainable Development, 6(11), 122.

Denicolai, S., Zucchella, A., \& Strange, R. (2014). Knowledge assets and firm international performance. International Business Review, 23(1), 55-62.

Eberhart, A. C., Maxwell, W. F., \& Siddique, A. R. (2004). An examination of long-term abnormal stock returns and operating performance following R\&D increases. The Journal of Finance, 59(2), 623650.

Gamayuni, R. R. (2015). The effect of intangible asset, financial performance and financial policies on the firm value. International Journal of Scientific \& Technology Research, 4(1), 202-212. 
García-García, J., \& de Magdaleno, M. A. (2010). Fair value on Open Source business. XIV Encuentro AECA, Coimbra (Portugal).

Garger, J. (2010). Equity and market value: How much is a company worth to an investor.

Grant, R. M. (1996). Toward a knowledge-based theory of the firm. Strategic Management Journal, (17S2), 109-122.

Hall, B. H., \& Lerner, J. (2010). The financing of R\&D and innovation. In Handbook of the Economics of Innovation (Vol. 1, pp. 609-639): Elsevier.

Helfat, C. E., \& Peteraf, M. A. (2003). The dynamic resource-based view: Capability lifecycles. Strategic Management Journal, 24(10), 997-1010.

Hsieh, P-H., Mishra, C. S., \& Gobeli, D. H. (2003). The return on R\&D versus capital expenditures in pharmaceutical and chemical industries. IEEE Transactions on Engineering Management, 50(2), 141-150.

Hsu, I-C., \& Sabherwal, R. (2011). From intellectual capital to firm performance: the mediating role of knowledge management capabilities. IEEE Transactions on Engineering Management, 58(4), 626-642.

Hulten, C. R., \& Hao, X. (2008). What is a Company Really Worth? Intangible Capital and the" Market to Book Value" Puzzle.

Jirásek, M. (2017). The Relationship Between R\&D Spending Instability and a Firm's Performance.

Jirásek, M. (2018). Financial Performance Feedback and R\&D: A Comparison of Different Models. Quality Innovation Prosperity, 22(1), 01-13.

Kalleberg, A. L., Marsden, P. V., Reynolds, J., \& Knoke, D. (2006). Beyond profit? Sectoral differences in high-performance work practices. Work and Occupations, 33(3), 271-302.

Kianto, A., Andreeva, T., \& Pavlov, Y. (2013). The impact of intellectual capital management on company competitiveness and financial performance. Knowledge Management Research \& Practice, 11(2), 112-122.

Kogut, B., \& Zander, U. (1992). Knowledge of the firm, combinative capabilities, and the replication of technology. Organization Science, 3(3), 383-397.

Kothari, S., Laguerre, T. E., \& Leone, A. J. (2002). Capitalization versus expensing: Evidence on the uncertainty of future earnings from capital expenditures versus R\&D outlays. Review of Accounting Studies, 7(4), 355-382.

Lantz, J-S., \& Sahut, J-M. (2005). R\&D investment and the financial performance of technological firms. International Journal of Business, 10(3), 251.

Leitner, K. H. (2005). Managing and reporting intangible assets in research technology organisations. $R \& D$ Management, 35(2), 125-136.

Lin, C-H., Yang, H-L., \& Liou, D.-Y. (2009). The impact of corporate social responsibility on financial performance: Evidence from business in Taiwan. Technology in Society, 31(1), 56-63.

Lome, O., Heggeseth, A. G., \& Moen, Ø. (2016). The effect of R\&D on performance: Do R\&D-intensive firms handle a financial crisis better? The Journal of High Technology Management Research, 27(1), 65-77.

Marrocu, E., Paci, R., \& Pontis, M. (2011). Intangible capital and firms' productivity. Industrial and Corporate Change, 21(2), 377-402.

Martin, M. (2015). Effectiveness of Business Innovation and R\&D in Emerging Economies: The Evidence from Panel Data Analysis. Journal of Economics Business and Management, 3(4), 440446.

Menor, L. J., Kristal, M. M., \& Rosenzweig, E. D. (2007). Examining the influence of operational intellectual capital on capabilities and performance. Manufacturing \& Service Operations Management, 9(4), 559-578.

Pandit, S., Wasley, C. E., \& Zach, T. (2011). The effect of research and development (R\&D) inputs and outputs on the relation between the uncertainty of future operating performance and R\&D expenditures. Journal of Accounting, Auditing \& Finance, 26(1), 121-144. 
Penman, S.H. (2009), Accounting for intangible assets: there is also an income statement. Abacus, 45(3), 358-371.

Peterson, R. A., \& Jeong, J. (2010). Exploring the impact of advertising and R\&D expenditures on corporate brand value and firm-level financial performance. Journal of the Academy of Marketing Science, 38(6), 677-690.

Rafiq, S., Salim, R., \& Smyth, R. (2016). The moderating role of firm age in the relationship between R\&D expenditure and financial performance: Evidence from Chinese and US mining firms. Economic Modelling, 56, 122-132.

Schimke, A., \& Brenner, T. (2014). The role of R\&D investments in highly R\&D-based firms. Studies in Economics and Finance, 31(1), 3-45.

Sehrawat, M., \& Giri, A. (2017). A Sectoral Analysis of the Role of Stock Market Development on Economic Growth: Empirical Evidence from Indian Economy. Global Business Review, 18(4), 911-923.

Sher, P. J., \& Yang, P. Y. (2005). The effects of innovative capabilities and R\&D clustering on firm performance: the evidence of Taiwan's semiconductor industry. Technovation, 25(1), 33-43.

Shin, N., Kraemer, K. L., \& Dedrick, J. (2009). R\&D, value chain location and firm performance in the global electronics industry. Industry and Innovation, 16(3), 315-330.

Siegel, J. J., \& Schwartz, J. D. (2006). Long-term returns on the original S\&P 500 companies. Financial Analysts Journal, 62(1), 18-31.

Teirlinck, P. (2017). Configurations of strategic R\&D decisions and financial performance in small-sized and medium-sized firms. Journal of Business Research, 74, 55-65.

Tubbs, M. (2007). The relationship between R\&D and company performance. Research-Technology Management, 50(6), 23-30.

VanderPal, G. A. (2015). Impact of R\&D Expenses and Corporate Financial Performance. Journal of Accounting and Finance, 15(7), 135.

Wang, C-H. (2011). Clarifying the Effects of R\&D on Performance: evidence from the high technology industries. Asia Pacific Management Review, 16(1), 51-64. 